\title{
НАСЛІДКИ РЕАЛІЗАЦІЇ ЗАГРОЗ ЕКОНОМІЧНІЙ БЕЗПЕЦІ ПІДПРИСМСТВА: СУТНІСТЬ ТА ТИПОЛОГІЗАЦІЯ
}

\section{Є. В. Міщук}

Криворізький національний університет

вул. В. Матусевича, 11, м. Кривий Ріг, 50027, Україна. Е-mail: tdutybz.077@gmail.com

Указано на бінарну сутність поняття «загроза», яка одночасно визначена як наслідок певної сукупності чинників і дій та причиною інших наслідків. Визначено, що наслідок реалізації загрози - це тернарне поняття, яке включає в себе процес, зміну та результат, які діалектично пов'язані та витікають одне із одного. Запропоновано амбівалентний підхід до розуміння природи наслідків реалізації загроз. Уточнено сутність поняття «наслідок» реалізації загрози, під яким запропоновано розуміти економічну категорію амбівалентної природи, яка виявляється у впливі на поточні й стратегічні економічні інтереси підприємства і його стейкхолдерів, характеризується як об'єктивними і прогнозованими властивостями, так і випадковими, ймовірними і непрогнозованими властивостями та визначається дуальною оцінкою. Розроблено класифікацію наслідків реалізації загроз, в якій застосовано нові ознаки. Запропоновано окремо визначати наслідки реалізації загроз для підприємства та його внутрішніх та зовнішніх стейкхолдерів, ураховуючи вплив на їх поточні й стратегічні економічні інтереси. Акцентовано увагу на кумулятивному та синергетичному ефектах щодо наслідків реалізації загроз. Виділено первинні, вторинні та результуючі наслідки. Представлено диференціацію наслідків на види та типи. Запропоновані теоретичні розробки щодо наслідків реалізації загроз економічній безпеці та розроблена матриця їх визначення сприятимуть більш об'єктивній їх оцінці, а також дозволить сформувати адекватну систему моніторингу та управління загрозами для підприємства та його стейкхолдерів.

Ключові слова: безпека, загроза, класифікація, наслідок, стейкхолдери.

\section{ПОСЛЕДСТВИЯ РЕАЛИЗАЦИИ УГРОЗ ЭКОНОМИЧЕСКОЙ БЕЗОПАСНОСТИ ПРЕДПРИЯТИЯ: СУЩНОСТЬ И ТИПОЛОГИЗАЦИИ}

\section{Е. В. Мищук}

Криворожский национальный университет

ул. В. Матусевич, 11, г. Кривой Рог, 50027, Украина. E-mail: tdutybz.077@gmail.com

Указано на бинарную сущность понятия «угроза», которая одновременно определена как следствие определенной совокупности факторов, а также действий и причин других последствий. Определено, что последствие реализации угрозы - это тернарное понятие, включающее в себя процесс, изменение и результат, которые диалектически связаны и вытекают одно из другого. Предложено амбивалентный подход к пониманию природы последствий реализации угроз. Уточнена сущность понятия «последствие реализации угрозы», под которым предлагается понимать экономическую категорию амбивалентной природы, которая проявляется в воздействии на текущие и стратегические экономические интересы предприятия и его стейкхолдеров, характеризуется как объективными и прогнозируемыми свойствами, так и случайными, вероятными и непредсказуемыми характеристиками и определяется дуальной оценкой. Разработана классификация последствий реализации угроз, в которой применены новые признаки. Предложено отдельно определять последствия реализации угроз для предприятия и его внутренних и внешних стейкхолдеров, учитывая влияние на их текущие и стратегические экономические интересы. Акцентировано внимание на кумулятивном и синергетическом эффектах от последствий реализации угроз. Выделены первичные, вторичные и результирующие последствия. Представлена дифференциацию последствий на виды и типы. Предложенные теоретические разработки последствий реализации угроз экономической безопасности и разработанная матрица их определения будут способствовать более объективной их оценке, а также позволит сформировать адекватную систему мониторинга и управления угрозами для предприятия и его стейкхолдеров.

Ключевые слова: безопасность, угроза, классификация, следствие, стейкхолдеры.

АКТУАЛЬНІСТЬ РОБОТИ. Дослідження економічної безпеки на різних рівнях (від безпеки людини до безпеки країни та світу) у більшості випадків супроводжуються аналізом загроз. Не заперечуючи його необхідності, вважаємо доцільним зробити акценти на іншому, не менш важливому понятті - наслідку. Існуюча система понять у галузі безпекології відрізняється різноманітністю поглядів, підходів (що об'єднуються у цілі наукові школи) не тільки до змісту найбільш уживаніших термінів, але й до їх складу. Однак не дивлячись на це, відсутні системні та комплексні дослідження поняття «наслідок» у предметно - об'єктній царині економічної безпеки.

Поняття «загрози» досліджує кожен науковець, який займається питаннями економічної безпеки.
Тому у науковій фаховій літературі воно є всебічно дослідженим та широко освітленим. При цьому не знайшло остаточного вирішення питання конкретизації поля загроз: діяльність підприємства, iї результати, інтереси тощо. Найбільш уживанішим терміном $є$ «загрози економічній безпеці». Так, учені I. О. Кузнецова та О. О. Кюне джерелом виникнення загроз економічній безпеці підприємства назвали чинники, що здійснюють свій вплив на стан безпеки [1]. Тому можемо зробити висновок, що загроза $\epsilon$ наслідком дії певних чинників. 3 іншого боку, називаючи загрозу таким розвитком подій, внаслідок яких збільшується можливість або з'являється вірогідність порушення нормального функціонування підприємства та заподіяння збитків, як це зробив 
В. Ф. Гапоненко із співавторами [2], випливає додаткове бачення: загрози мають власні наслідки. Ураховуючи підхід, запропонований колективом авторів на чолі з О. М. Підхомним, згідно якого загроза - це «потенційні або реальні дії фізичних чи юридичних осіб, що порушують стан захищеності суб'єкта підприємницької діяльності та здатні призвести до припинення його діяльності або до фінансових й інших втрат» [3], робимо остаточний висновок про наявність різних наслідків за умови реалізації дії загроз.

Дискусія серед науковців точиться щодо пари понять «загроза - небезпека». Так, Х. І. Цвайг i Н. В. Галайко [4] уточнили, що кожному з існуючих визначень поняття «загроза» протиставлена небезпека нанесення фінансової шкоди, що проявляється у вигляді збитків, негативного впливу, перешкод в досягненні цілей тощо, при цьому загроза є чинником, який генерує значну небезпеку стійкому функціонуванню економічної системи. На їх думку, поняття «загроза» більш широке, ніж поняття «небезпека». Прояв небезпеки у вигляді реальних втрат вони пропонують розглядати «як сигнал можливого переростання iї в загрозу, якщо не будуть прийняті відповідні заходи» [4].

Другою парою понять, які співтавляються у безпекогії, є ризик і загроза. Їх відмінність показано в роботі М. Б. Кристиняк: «спершу існує ризик, а пізніше - загроза, ... ризики постійно супроводжують підприємницьку діяльність, мають імовірність настання негативної події та неотримання очікуваних результатів, а загрози несуть за собою втрату ресурсів, перешкоду цілям та завданням суб'єктів господарювання у результаті впливу негативних внутрішніх чи зовнішніх факторів» [5]. А ось науковець $\mathrm{H}$. Реверчук загрозу вважає видом небезпеки і за величиною можливих наслідків він виділяє такі види небезпек: попередження, ризик, загроза [6].

Іншим напрямком у дослідженні питань щодо економічної безпеки підприємства $є$ ототожнення певних наслідків для підприємства із формою прояву загроз. Це показано, наприклад, 3. В. Якубовичем, який проявами суб'єктивних загроз, викликаних неефективною роботою підрозділів підприємства, його керівництва або окремих працівників, назвав низьку конкурентоспроможність, нестійкість фінансового стану підприємства тощо [7]. Прояви загроз визначаються, здебільшого, видом безпосередньо тієї чи іншої загрози.

Поняття «наслідок», звичайно, присутне в працях $з$ економічної безпеки [2-4], але не явним чином, більше як прояв загроз. Мало уваги приділено його змісту, типологізації, оцінюванню тощо. Вважаємо, що відповідь на питання, які ж саме наслідки того, що підприємство не досягне бажаного рівня економічної безпеки або не зможе його забезпечити належним чином і у встановлені строки обумовлює актуальність даного напрямку дослідження.

Мета статті полягає в уточненні сутності поняття «наслідок» реалізації загроз й систематизації його типів і видів.

МАТЕРІАЛ І РЕЗУЛЬТАТИ ДОСЛІДЖЕНЬ. Згідно з академічним тлумачним словником, наслідок - це «те, що виходить, випливає з чого-небудь; результат» (Словник української мови: в 11 томах, том 5, 1974, с. 192). Англійською його переклад більш різноманітний: consequence (наслідок, висновок), aftermath (наслідок), outcome (наслідок, результат, розв'язка, вихід), sequel (продовження, результат, наслідок, наступна подія), subsequence (наслідок), consequent (наслідок, результат), sequela (ускладнення, наслідок), train (наслідок), after-effect (наслідок, результат). Своєю чергою, результат (від фр. «rйsultat», від лат. «resultatum» - «те, що вискочило»), підсумок) - це кінцевий наслідок послідовності дій (Етимологічний словник української мови: у 7 т., т. 5: Р - Т / укл.: Р. В. Болдирєв та ін. Київ: Наукова думка, 2006. 704 с.). Як видно, в етимологічному плані існує замкнене коло: наслідок - це результат, а результат - це наслідок. Очевидно, що наслідки ведуть до змін. Зміни можуть характеризуватися новими значеннями показників, іншими підходами до бізнес-процесів тощо. Загалом, зміна - це «перехід, перетворення чого-небудь (перев. стану, руху, ознаки, властивості і т. ін.) у щось якісно інше; змінювання» (Словник української мови: в 11 томах, том 3, 1972, с. 621). Відтак поняття наслідок, зміна та результат пов'язані між собою й витікають одне 3 одного. У цьому контексті вважаємо, що наслідок прояву загрози - це тернарне поняття, яке включає в себе процес, зміну та результат, які діалектично пов'язані та витікають одне із одного. Схематично зобразимо їх на рис. 1 .

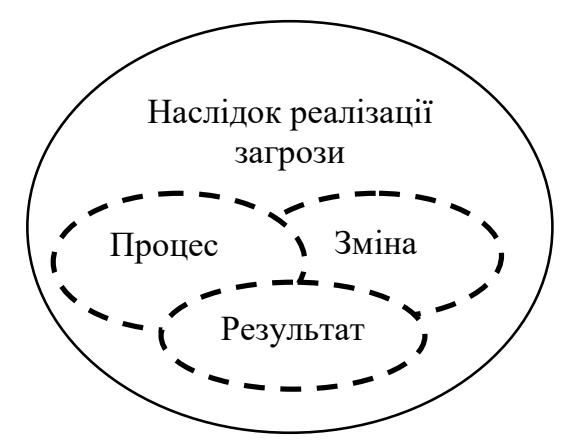

Рисунок 1 - Наслідок прояву загрози економічній безпеці (розроблено автором)

Крім того, слід указати на бінарну сутність поняття «загроза», оскільки, як показано вище, вона одночасно є наслідком певної сукупності чинників і дій та причиною інших наслідків. Принциповим $є$ 
те, що одна й та сама загроза, у разі іiі реалізації, може мати різні наслідки та різні результати для підприємства та його стейкхолдерів. Крім цього, не кожна загроза, навіть у разі іiі реалізації, матиме наслідки щодо зміни рівня економічної безпеки підприємства. Тому для ефективного моніторингу пропонуємо розробляти на підприємстві відповідні матриці, в яких по горизонталі слід розташовувати конкретні загрози, а по вертикальні - наслідки їх реалізації для самого підприємства та для його стейкхолдерів 3 метою виявлення тих із них, що ведуть до зміни рівня економічної безпеки.

Надалі, ураховуючи відсутність однозначності у понятійно-категоріальному апараті відмітимо, що в межах даного дослідження на основні дефініцій, запропонованих М.I. Небавою та О.Ю. Міроновою (Небава М. І., Міронова Ю.В.Економічна безпека підприємств: навчальний посібник. Вінниця: ВНТУ, 2017. 73 с., с.45) уточнимо зміст відповідних термінів і вважаємо доцільним вживати їх у такому значенні: «індикатори економічної безпеки - це реальні статистичні показники діяльності підприємства, які найбільш повно відображають сутність економічної безпеки; оптимальні значення індикаторів - це інтервал величин, у межах яких створюються найбільш сприятливі умови для діяльності підприємства та підтримання економічної безпеки на належному рівні; порогові значення індикаторів - це кількісні величини, порушення яких викликає несприятливі наслідки, тенденції для рівня економічної безпеки; граничні значення індикаторів - це кількісні величини, порушення яких викликає загрозливі процеси».

Очевидним $є$ той факт, що зміна рівня економічної безпеки обумовлюються зміною індикаторів, які іiі характеризують. Своєю чергою, зміна цих індикаторів викликає різного роду наслідки як для самого підприємства, так і для його стейкхолдерів. При цьому наслідки можуть бути як позитивного, так і негативного характеру.
Класифікувати наслідки реалізації загроз, у т.ч. наслідки відсутності заданого підприємством рівня економічної безпеки можна за різними класифікаційними ознаками. Насамперед, це внутрішні та зовнішні наслідки. Перші впливають на особливості діяльності безпосередньо підприємства та його працівників, а другі - на його зовнішніх стейкхолдерів. Наслідки реалізації загроз можуть мати прямий i непрямий вплив як на діяльність підприємства, так і на його стейкхолдерів. Такі наслідки доцільно розділити на групи за ознакою сили впливу на них: наслідки, які надають сильний вплив, помірний вплив або слабкий вплив. При цьому окремого дослідження вимагає відповідна шкала оцінювання сили впливу наслідків реалізації конкретної загрози на певні економічні показники, серед яких імовірність банкрутства та ліквідації підприємства. Крім того, з точки зору масштабів охоплення наслідки можуть бути локальними (проявлятися в одному виді діяльності підприємства або на одній групі стейкхолдерів) і загальними (охоплювати всю діяльність або усі групи стейкхолдерів підприємства).

Зовнішні наслідки реалізації загроз на підприємстві можуть класифікуватися таким чином:

- економічні, що передбачають вплив на економіку регіону та усієї країни через скорочення податкових надходжень, вплив на обсяги валового внутрішнього продукту тощо;

- соціальні, що характеризуються страйками, зростанням злочинності, безробіття тощо;

- екологічні наслідки, які можна диференціювати на негативні (забруднення навколишнього середовища) та позитивні (покращення екологічної обстановки унаслідок зупинки чи закриття виробництва). Внутрішні наслідки доцільно диференціювати на ті, що впливають на економічні інтереси самого підприємства та на ті, що впливають на інтереси його внутрішніх стейкхолдерів (рис. 2).

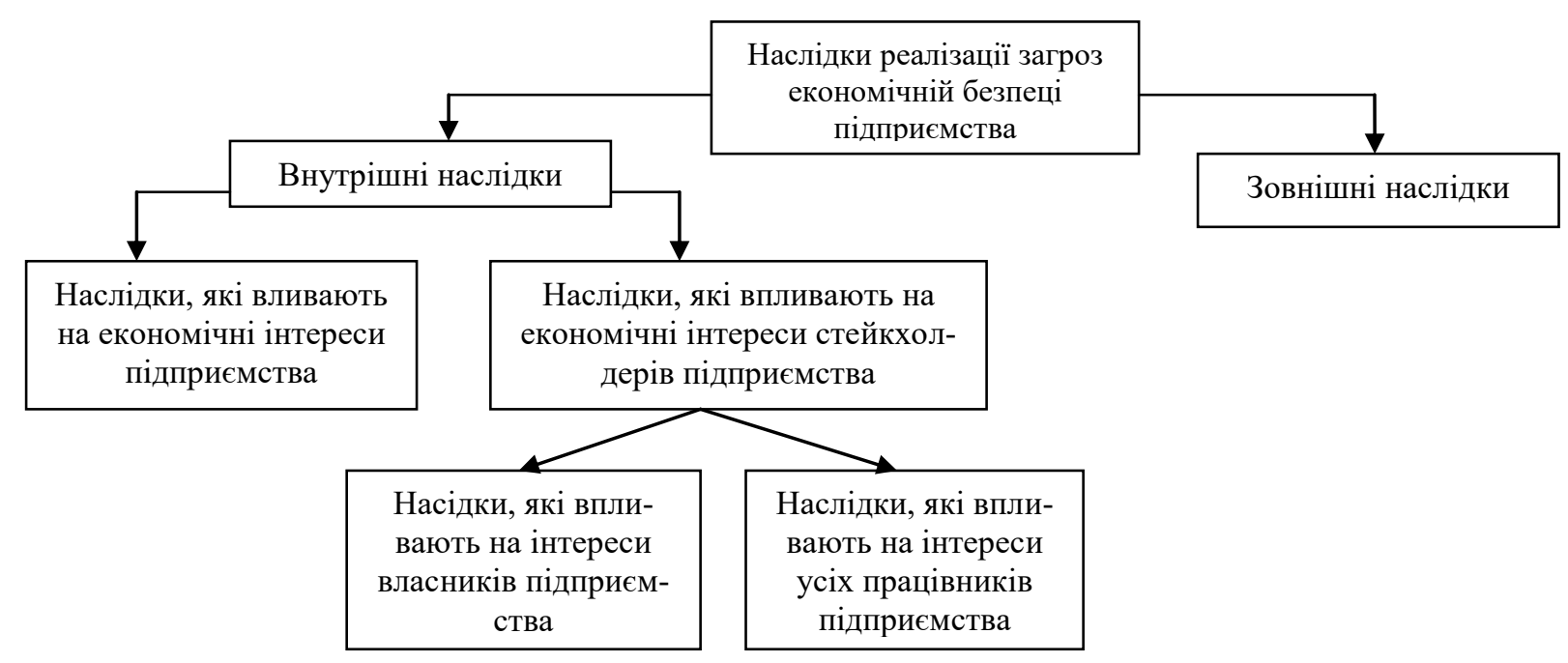

Рисунок 2 - Зріз класифікації наслідків реалізації загроз економічній безпеці підприємства (розроблено автором)

Запропонована класифікація може бути додатково доповнена та розгалужена конкретизацією еко- номічних інтересів підприємства та, відповідно інтересів його стейкхолдерів на фінансові, соціальні, 
екологічні, юридичні та інші. Крім того, можна виділити види наслідків аналогічні зовнішнім (економічні, соціальні, екологічні), але 3 іншим змістовним наповненням та доповненням у вигляді фінансових, виробничих, репутаційних, інвестиційних, інформаційних, юридичних та інших видів наслідків. Разом iз цим, важливо розрізняти наслідки, що впливають на поточні інтереси, і наслідки, які вливають на стратегічні інтереси підприємства та його стейкхолдерів.
При цьому можливі дискусійні моменти пов'язані з рядом питань. Одним із них є те, до якого виду наслідку віднести ліквідацію підприємства. 3 однієї сторони, це результуючий економічний наслідок відсутності економічної безпеки, а з іншої це юридичний наслідок реалізації загроз.

Розглядаючи екологічні наслідки, слід звернути увагу на їх економічні та соціальні підвиди (табл. 1).

Таблиця 1 - Можливі екологічні наслідки реалізації загроз економічній безпеці підприємства (узагальнено автором)

\begin{tabular}{|l|l|}
\hline Можливий наслідок & \multicolumn{1}{|c|}{ Зміст наслідку } \\
\hline 1. Економічний & $\begin{array}{l}\text { Збільшення матеріальних витрат; зниження конкурентоспроможності підприємства } \\
\text { через невідповідність екологічним стандартам продукції; зменшення обсягів вироб- } \\
\text { ництва продукції; недоотримання доходів і прибутку. }\end{array}$ \\
\hline 2. Соціальний & $\begin{array}{l}\text { Скорочення чисельності населення у зв'язку зі збільшенням смертності через неспри- } \\
\text { ятливу екологічну обстановку, а також у зв'язку з низькою народжуваністю; міграція } \\
\text { населення з забруднених територій на більш чисті. }\end{array}$ \\
\hline
\end{tabular}

Наслідки реалізації загроз можуть бути диференційовані й за іншими класифікаційними ознаками. Однак їх слід називати не видами, а типами наслідків. При цьому різні види та різні типи наслідків створюють різні комбінації, які не є сталими і змінюються як в часі, так і просторі (залежно від окремих умов, ситуацій тощо). Так, за ймовірністю настання доцільно розділити на такі типи: наслідки, які настануть $з$ високою часткою ймовірності, середньої, або низькою. За можливістю прогнозування наслідки можуть бути непрогнозованими і прогнозованими. Крім того, наслідки реалізації загроз, у т.ч. наслідки відсутності заданого рівня економічної безпеки на підприємстві можуть бути випадковими і закономірними.

3 урахуванням періоду впливу на підприємство та його стейкхолдерів, а також за періодом усунення наслідків, їх можна поділити на типи: короткострокі, середньострокові та довгострокові.

За можливістю подолання наслідки можна розділити таким чином: повністю переборні наслідки; частково переборні наслідки; непереборні наслідки.

За ознакою залученості ресурсів у процес подолання наслідків можна розрізняти такі типи: наслідки, які усуваються власними ресурсами; наслідки, які усуваються залученими ресурсами; наслідки, які усуваються змішаними ресурсами (частково власними і частково залученими).

Наслідки реалізації загроз, у т.ч. наслідки відсутності заданого рівня економічної безпеки на підприємстві можуть бути затухаючі, рівномірно зростаючі та зростаючі за принципом «сніжного кому».

Різні наслідки, які збіглися в часі, можуть доповнювати і підсилювати один одного, тим самим породжуючи нові види й нові типи наслідків та сворювати їх нові комбінації. Водночас може мати місце певний синергетичний ефект. При цьому для різних стейкхолдерів і для різних напрямків діяльності підприємства один і той самий наслідок може генерувати інші різновекторні наслідки: як позитивного, так і негативного характеру. Наприклад, зупинка виробництва носить негативні наслідки для еконо- мічних інтересів як самого підприємства, так і його власників і персоналу, проте має позитивні наслідки для громади через покращення екології (i, можливо, здоров'я мешканців довколишньої території). У такому разі важливо знайти показник, який дозволить з'єднати різновекторні наслідки і зробити висновки.

У роботі [8] нами враховано можливість загроз переходити одна в іншу і запропоновано ураховувати цю можливість не тільки за групами стейкхолдерів (загрози підприємству - загрози власникам), а й за видами безпеки (на прикладі інвестиційної безпеки). Аналогічно пропонуємо при визначенні наслідків реалізації загроз економічній безпеці та окремо іiі складовим (інвестиційній безпеці, фінансовій тощо) враховувати можливості переходу одних видів наслідків в інші. Отже, одні наслідки можуть породжувати інші, вони мають кумулятивний ефект. При цьому пропонуємо розрізняти первинні наслідки, вторинні та результуючі наслідки.

Синтезуючи окремі положення 3 теорії організацій в теорію безпекології, використовуємо відомий підхід до розкриття функціонування і розвитку організацій, який називається амбівалентним. Він полягає в поєднанні, з одного боку, об'єктивних і прогнозованих засад, а з іншого боку - випадкових, нестійких, імовірнісних, непрогнозованих засад (Демчук О.Н., Ефремова Т.А Теория организаци. Москва: Флинта: МПСИ, 2009. 264 с.). Безпосередньо термін амбівалентність (з латині «атbо» перекладається як «обидва», а «valentia» - як «сила») запозичений 3 психології та означає неоднозначне, суперечливе ставлення до кого-небудь або чогось. При цьому в економіці амбівалентність використовують для характеристики соціально-економічної позиції підприємництва, яка проявляється в боротьбі ідей. Автор роботи [9] протиставляє позицію К. Маркса (згідно 3 якою підприємець і власник за своєю суттю $є$ капіталістами, які всього лише виконують функціональні ролі і їм слід протиставляти найманого робітника) позиції А. Маршалла, Й. Шумпетера та ін. (відповідно до якої підприємець виконує соціальноекономічну функцію, створюючи робочі місця). 
Отже, один і той же наслідок у різних ситуаціях може бути сприйнято позитивно або негативно для даного підприємства (наприклад, коли стан безпеки стримував розвиток, якому притаманні ризики). Крім того, наслідок, який для однієї групи стейкхолдерів буде позитивним, для іншої може стати вкрай негативним. Дані висновки дозволяють нам стверджувати про доцільність амбівалентного підходу до розуміння наслідків реалізації загроз у цілому та відсутності заданого рівня економічної безпеки на підприємстві зокрема (рис. 3).

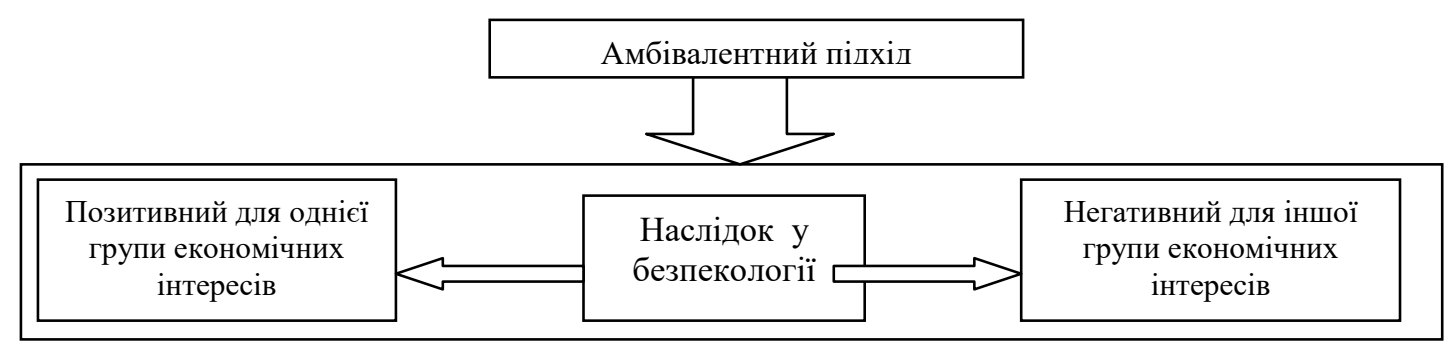

Рисунок 3 - Амбівалентний підхід до сутності поняття «наслідок» у безпекології (розроблено автором)

Як вірно відзначила C.I. Пучкова, в Кодексі законів про працю України зазначено ряд документів, дотримання яких безпосередньо впливає на безпеку підприємства, і які служба персоналу зобов'язана забезпечити з метою відсутності негативних юридичних наслідків [10]. Ураховуючи це, доцільно виділити юридичні наслідки відсутності заданого рівня економічної безпеки, які у кінцевому підсумку можуть привести до економічних, і навпаки.

Слід звернути увагу на те, що виділені нами види та типи наслідків реалізації загроз можуть поєднуватися та створювати нові комбінації наслідків. Наприклад, економічний наслідок може бути також прогнозованим, довготривалим, негативним, частково переборним і таким, що усувається тільки позиковими ресурсами тощо. Для більш поглибленого дослідження найбільш вдало будувати відповідні матриці, в яких по горизонталі зображати види наслідків, а по вертикалі - різні типи наслідків. Додат- ково слід указати, що нами розглянуто наслідки реалізації загроз для економічної безпеки в цілому, тоді як окремого дослідження потребують наслідки реалізації загроз для іiї окремих складових фінансової безпеки, кадрової, силової та інших.

Окремо слід розглядати наслідки реалізації загроз, що проявляються у зміні трендів індикаторів економічної безпеки підприємства та іï складників. Так, окрім кількісного впливу на важливі економічні показники, наслідки реалізації загроз можуть виявлятися в зміні напрямків інвестування, використання прибутку тощо. При цьому уваги заслуговує твердження, що виникнення кумулятивного зростання величини відхилень тих чи інших показників від довгострокової тенденції їх зміни $є$ сигналом про виникнення кризи [11]. При цьому доцільно зупинитися на специфічних, притаманних їм видам та типам наслідків у межах розробленої нами класифікації, поданої на рис. 2 (табл. 2).

Таблиця 2 - Приклад можливої матриці визначення наслідків реалізації загроз (розроблено автором)

\begin{tabular}{|c|c|c|c|c|c|c|c|}
\hline Наслідки & \multicolumn{7}{|c|}{ Типи наслідків } \\
\hline Для підприємства & \multicolumn{3}{|c|}{ Поточні } & \multicolumn{3}{|c|}{ Стратегічні } & \multirow[t]{2}{*}{ Специфічні } \\
\hline Види наслідків & Ознака 1 & $\ldots$ & Ознака $\mathrm{n}$ & Ознака 1 & $\ldots$ & Ознака $\mathrm{n}$ & \\
\hline Економічні & Негативні & $\mathrm{x}$ & Переборні & Локальні & $\mathrm{x}$ & Затухаючі & Часові \\
\hline Фінансові & Негативні & $\mathrm{x}$ & Переборні & Локальні & $\mathrm{x}$ & Затухаючі & Часові \\
\hline Соціальні & Негативні & $\mathrm{x}$ & Переборні & Локальні & $\mathrm{x}$ & Затухаючі & Часові \\
\hline Екологічні & Негативні & $\mathrm{x}$ & Переборні & Локальні & $\mathrm{x}$ & Затухаючі & Часові \\
\hline Юридичні & Негативні & $\mathrm{x}$ & Переборні & Локальні & $\mathrm{x}$ & Затухаючі & Часові \\
\hline$\ldots$ & Негативні & $\mathrm{x}$ & Переборні & Локальні & $\mathrm{x}$ & Затухаючі & Часові \\
\hline $\begin{array}{c}\text { Для стейкхолдерів } \\
\text { (окремо за кожною їх групою) }\end{array}$ & Негативні & $\mathrm{x}$ & Переборні & Локальні & $\mathrm{x}$ & Затухаючі & Часові \\
\hline$\ldots$ & Негативні & $\mathrm{x}$ & Переборні & Локальні & $\mathrm{x}$ & Затухаючі & Часові \\
\hline
\end{tabular}

У табл. 2 приведено найпростіший приклад, коли всім видам наслідків відповідають однакові типи. Проте у практичній діяльності підприємств кожному виду наслідків відповідатимуть кілька типів, причому різних для різних їх видів.

На особливу увагу, на наш погляд, заслуговує специфічний вид наслідків - часовий. У зв'язку 3 цим, пропонуємо визначати наслідки двох родів.

Наслідки першого роду - це достатньо висвітлені у фаховій літературі наслідки від недосягнення індикаторами економічної безпеки по кожній іiі складовій планових (порогових) значень, що можуть бути оцінені у грошовому або іншому (натуральному) вираженні.

Наслідки другого роду - це наслідки від зміни часу, необхідного для досягнення (забезпечення) економічної безпеки у цілому та кожної іiї складової окремо. 3 іншої сторони, дефіцит або запас часу, отриманий підприємством є також наслідком певних чинників.

Отже, слід указати на дуальність оцінки наслідків недотримання заданого рівня економічної безпеки, що обумовлюється їх одночасним впливом на натуральні (грошові) та часові (темпоральні) показ- 
ники. Цікавий підхід до врахування фактора часу викладено Т. О. Меліховою, яка пропонує розрахувати валовий, чистий, дійсний та заданий періоди повернення витрат, пов'язаних з економічною безпекою підприємства [12]. В основу оцінювання цих періодів покладено визначення відповідно умовного, чистого та валового прибутку й грошового потоку. Вважаємо, що даний підхід доцільно застосувати до інших індикаторів економічної безпеки підприємства та його стейкхолдерів. Наприклад, за цим підходом можна визначити наслідки та відповідні періоди для масштабу бізнесу, який, своєю чергою, оцінюються $з$ використанням загальновідомого показника середньомісячної виручки (який розраховується поділом валової виручки по оплаті до числа місяців періоду [13]); при цьому визначимо умовну, дійсну та чисту виручку і відповідні періоди, необхідні для iï отримання. Відтак аналогічним чином доцільно визначати не тільки усі показники, в яких застосовуються показники прибутку та грошового потоку, але й інші, такі як моделі прогнозування банкрутства та ліквідації. Застосовуючи такий підхід можна отримати систему показників, які характеризуватимуть рівень економічної безпеки загалом та іï окремих складових зокрема. При цьому диференціація періодів буде за кількома напрямками: за періодами отримання різних рівнів економічної безпеки загалом та іiі функціональних складових зокрема. Дані періоди, своєю чергою, складатимуться із періодів досягнення прийнятних значень відповідними індикаторами. При цьому градація періодів буде конкретизована не тільки в залежності від економічного змісту показника - індикатора, але й відбивати особливості лінгвістичної інтерпретації рівня економічної безпеки (наприклад, високий, середній, низький, катастрофічний).

Описані нами наслідки - від зміни часу та від зміни тенденції можуть носити як позитивний, так і негативний характер. Якщо наслідки носять негативний характер, то це втрати або збитки підприємства. Величину таких втрат (збитків) доцільно додавати до суми інвестицій, які спрямовуються на заходи, що прямо або опосередковано сприятимуть мінімізації (чи повному усуненню) наслідків реалізації загроз економічній безпеці підприємства та його стейкхолдерам.

Відтак наслідки у безпекології можна диференціювати за різними ознаками. Водночас слід визнати, що прагнучи до всеосяжності при класифікації, у дійсності, охопити весь їх спектр неможливо. Це пов'язано з тим, що при конкретизації наслідків, їх перелік змінюються не тільки в залежності від тієї чи іншої складової економічної безпеки (очевидно, що загрози фінансовій спроможності та загрози екологічній безпеці переважно різні), але й від ряду чинників. До останніх слід віднести стадії життєвих циклів підприємства й галузі, циклічність економіки та інші.

ВИСНОВКИ. Таким чином, запропоновано амбівалентний підхід до розуміння природи наслідків реалізації загроз. Даний підхід передбачає поєднання в конкретному наслідку як об'єктивних і прогнозованих засад, так і випадкових, нестійких, імовірні- сних, непрогнозованих засад. Обгрунтовано, що наслідок $\epsilon$ також амбівалентним 3 точки зору різних груп стейкхолдерів підприємства. Раніше амбівалентний підхід в економіці використовувався для характеристики підприємництва, а в теорії безпекології вченими не застосовувався. Уточнюючи сутність поняття «наслідок» відсутності (недотримання) заданого рівня економічної безпеки на підприємстві, пропонуємо розуміти під ним економічну категорію амбівалентної природи, яка виявляється у впливі на поточні й стратегічні економічні інтереси підприємства і його стейкхолдерів, характеризується як об'єктивними i прогнозованими властивостями, так i випадковими, ймовірними і непрогнозованими властивостями та визначається дуальною оцінкою.

На підставі проведеного аналізу літературних джерел щодо суті загроз та їх проявів, а також власних досліджень, розширено класифікацію наслідків реалізації загроз, у т.ч. наслідків відсутності заданого рівня економічної безпеки, яка, на відміну від існуючих, включає більше число класифікаційних ознак, а також передбачає їх нові комбінації.

\section{ЛІТЕРАТУРА}

1. Кузнецова I. О., Кюне О. О Класифікація загроз економічній безпеці підприємства. Вісник соиіально-економічних досліджень: зб. наук. Пращь. Одеса: Одеський національний економічний університет. 2015. Вип. 3. № 58. С. 120-128.

2. Гапоненко В. Ф., Безпалько А. А. Экономическая безопасность предприятия: подходы и принципы: монография. Москва: Ось-89, 2006. 208 с.

3. Підхомний О. М., Микитюк Н. О. Типологія загроз фінансовій безпеці суб'єктів підприємницької діяльності. Менеджмент та підприємництво в Україні: етапи становлення $і$ проблеми розвитку. Львів: Вид-во НУ «Львівська політехніка». 2007. С. $119-123$.

4. Цвайг Х. І., Галайко Н. В. Загрози фінансовій безпеці підприємства та шляхи їх усунення. Причорноморські економічні студії. 2016. Вип. 11. C. $181-185$.

5. Кристиняк М. Б. Визначення загроз для економічної безпеки малого підприємства та формування алгоритму протидії їм. Наукові записки Української академії друкарства. Серія: Економічні науки. 2016. № 2(53). С. 270-276.

6. Реверчук Н. Й. Управління економічною безпекою підприємницьких структур: монографія. Львів: ЛБІ НБУ, 2004. 195 с.

7. Якубович 3. В. Ідентифікація загроз економічній безпеці машинобудівного підприємства. Галицький економічний вісник. 2010. № 3 (28). С. 107112.

8. Міщук С. В., Адамовська В. С. Аналіз загроз інвестиційній безпеці підприємства та інвесторів. Економіка та держава. 2015. №1. С. 30-32.

9. Алексеев О. А. Амбивалентность предпринима-тельства: противоречивость экономической функции, конфликт интересов. Проблемы современной экономики. 2008. №1 (25). С. 151-153.

10. Пучкова С. І. Методичні підходи щодо забезпечення кадрової безпеки підприємства. Науково- 
методичні аспекти забезпечення економічної безпеки: монографія; за заг. ред. І. О. Кузнецової. Одеса: Атлант, 2013. С. 123-132.

11. Рамазанов С. К. Інноваційні технології антикризового управління: монографія. Левашева Л. В., Степаненко О. П., Тимашова Л. А. Варшавак: Видво СНУ ім. В. Даля, 2009. 262 с.

12. Меліхова Т. О. Модель створення системи економічної безпеки підприємства: економічна ефе- ктивність витрат у короткостроковому періоді. Bicник Кременчуцького національного університету імені Михайла Остроградського. 2018. Вип. 1 (108). C. $154-159$.

13. Хоменко Л. М., Дідур С. В. Підвищення ефективності виробничо-фінансової діяльності вагонобудівного підприємства. Вісник Кременчуиьького національного університету імені Михайла Остроградського. 2018. Вип. 3 (110). С. 103-109.

\section{CONSEQUENCES OF IMPLEMENTATION OF THREATS TO ECONOMIC SECURITY OF THE ENTERPRISE: ESSENCE AND TYPOLOGIZATION}

\section{Ie. Mishchuk}

Kryvyi Rih National University

vul. Vitalyy Matusevych, 11, Kryvyi Rih, 50027, Ukraine. E-mail: tdutybz.077@gmail.com

Purpose. The purpose of the article is to clarify the essence of the concept of "consequence" of the implementation of threats in particular, and the lack of an adequate level of economic security of an enterprise in particular and systematization of its types and types. Findings. The binary essence of the concept "threat" is revealed, which is simultaneously determined as a consequence of a certain combination of factors and actions, as well as the cause of other consequences. It is determined that the manifestation of a threat is a three-way concept, which includes the consequence, the change and the result, which are dialectically related and give rise to one another. It is proposed to separately determine the consequences of threats to the enterprise and for its internal and external stakeholders. The need to take into account the cumulative and synergistic effects of the effects of threats is indicated. Primary, secondary and resulting effects are highlighted. The differentiation of the effects on the species and types is presented. Methodology. The study used general scientific theoretical methods: generalization, explanation, grouping - to analyze the views of economists on the subject of research and formulate conclusions from a meaningful analysis of original sources, analysis and synthesis - to clarify the main scientific categories of research, substantiate new concepts, principles, concepts and categories: "threat", "ambivalent approach", "consequence" of the lack of an adequate level of economic security; schematic and graphical image - for visual presentation of the results. Practical value. The proposed theoretical developments on the consequences of the lack of an adequate level of economic security in an enterprise will contribute to a more objective assessment of them, as well as allow an adequate system of monitoring and managing threats for the enterprise and its stakeholders to be formed. Results. The essence of the concept of "consequence" of the lack of an adequate level of economic security of an enterprise has been clarified, by which it is proposed to understand the economic category of an ambivalent nature, which is manifested in the impact on the current and strategic economic interests of the enterprise and its stakeholders, as well as characterized by both objective and predictable properties, as well as random , probable and unpredictable properties and is determined by a double estimate. The classification of the consequences of the realization of threats has been expanded, which, unlike the existing ones, includes a greater number of classification features and also provides for their new combinations. References 13, tables 2, figures 3.

Key words: security, threat, classification, consequence, manifestation, stakeholders

\section{REFERENCES}

1. Kuznetsova, I. O., Kiune, O. O. (2015), Klasyfikatsiia zahroz ekonomichnii bezpetsi pidpryiemstva» [The classification of threats to the economic security of the enterprise], Visnyk sotsialno-ekonomichnykh doslidzhen: $z$ b. nauk. prats [Bulletin of socio-economic research: a collection of scientific papers], Odesa, Vol. 3, no 58, pp. 120-128.

2. Gaponenko, V. F., Bezpalko, A. A. (2006), Ekonomicheskaya bezopasnost predpriyatiya: podkhody $i$ printsipy [Economic security of an enterprise: approaches and principles], Moskva: Os-89.

3. Pidkhomnyi, O. M., Mykytiuk, N. O. (2007), "Typolohiia zahroz finansovii bezpetsi subiektiv pidpryiemnytskoi diialnosti" [Typology of threats to financial security of business entities], Menedzhment ta pidpryiemnytstvo $v$ Ukraini: etapy stanovlennia $i$ problemy rozvytku [Management and entrepreneurship in Ukraine: the stages of formation and development problems], Lviv: Vydavnytstvovo NU «Lvivska politekhnika», pp. 119-123.

4. Tsvaih, Kh. I., Halaiko, N. V. (2016), "Zahrozy finansovii bezpetsi pidpryiemstva ta shliakhy yikh usunennia" [Threats to the financial security of the enterprise and ways to eliminate them], Prychornomorski ekonomichni studii [Black Sea economic studios], Vol. 11, pp. $181-185$.

5. Krystyniak, M. B. (2016), "Vyznachennia zahroz dlia ekonomichnoi bezpeky maloho pidpryiemstva ta formuvannia alhorytmu protydii yim" [Identification of threats to the economic security of a small enterprise and the formation of an algorithm to counter them], Naukovi zapysky Ukrayinskoi akademii drukarstva [Science Notes of the Ukrainian Academy of Friendship], Seriia: Ekonomichni nauky, no 2(53), pp. 270-276.

6. Reverchuk, N. Y. (2004), Upravlinnia ekonomichnoiu bezpekoiu pidpryiemnytskykh struktur [Management of economic security of business structures], Lviv: LBI NBU.

7. Iakubovych, Z. V. (2010), "Identyfikatsiia zahroz ekonomichnii bezpetsi mashynobudivnoho pidpryiemstva" [Identifying threats to the economic security of a machine-building enterprise], Halytskyi ekonomichnyi visnyk [Galician Economic Bulletin], no 3 (28), pp. 107-112. 
8. Mishchuk, Ye. V., Adamovska, V. S. (2015), "Analiz zahroz investytsiinii bezpetsi pidpryiemstva ta investoriv" [Analysis of threats to investment security of the enterprise and investors], Ekonomika ta derzhava [Economy and state], no 1, pp. 30-32.

9. Alekseev, O. A. (2008), “Ambivalentnost predprinimatelstva: protivorechivost ekonomicheskoy funktsii, konflikt interesov" [Entrepreneurial ambivalence: inconsistency of economic function, conflict of interests], Problemy sovremennoy ekonomiki [Problems of the modern economy], no 1 (25), pp. 151-153.

10. Puchkova, S. I. (2013), Metodychni pidkhody shchodo zabezpechennia kadrovoi bezpeky pidpryiemstva. Naukovo-metodychni aspekty zabezpechennia ekonomichnoi bezpeky [Methodical approaches to ensuring personnel security of the enterprise. Scientific and methodological aspects of ensuring economic security], Odesa: Atlant.

11. Ramazanov, S. K. (2009), Innovatsiini tekhnolohii antykryzovoho upravlinnia [Innovative technologies of crisis management], Varshavak: Vydavnytstvovo SNU im. V. Dalia.
12. Melikhova, T. O. (2018), "Model stvorennia systemy ekonomichnoi bezpeky pidpryiemstva: ekonomichna efektyvnist vytrat u korotkostrokovomu periodi" [Model for creation of the enterprise economic security system: economic cost effectiveness in a shortterm period], Visnyk Kremenchutskoho natsionalnoho universytetu imeni Mykhaila Ostrohradskoho [Bulletin of the Kremenchug National University of Ostrogradsky], Vol. 1 (108), pp. $154-159$.

13. Khomenko, L. M., Didur, S. V. (2018), "Pidvyshchennia efektyvnosti vyrobnycho-finansovoi diialnosti vahono-budivnoho pidpryiemstva" [Increase of effectiveness of operational and financial activities of a carriage-building enterprise], Visnyk Kremenchutskoho natsionalnoho universytetu imeni Mykhaila Ostrohradskoho [Transactions of Kremenchuk Mykhailo Ostrohradskyi National University], Vol. 3 (110), pp. 103 - 109.

Стаття надійшла 03.06.2019. 